\title{
Ocean-fertilization project off Canada sparks furore
}

\section{Bid to boost salmon stocks relied on hotly debated science and dubious carbon credits.}

\section{BY JEFF TOLLEFSON}

$\mathrm{W}$ hen a chartered fishing boat strewed 100 tonnes of iron sulphate into the ocean off western Canada last July, the goal was to supercharge the marine ecosystem. The iron was meant to fertilize plankton, boost salmon populations and sequester carbon. Whether the ocean responded as hoped is not clear, but the project has touched off an explosion on land, angering scientists, embarrassing a village of indigenous people and enraging opponents of geoengineering.

The first reports about the project, which appeared in British newspaper The Guardian on 15 October, presented it as a rogue geoengineering scheme - the largest in history — in "blatant violation" of international treaties. Critics suggested that Russ George, a US entrepreneur, had persuaded the Haida Nation village of Old Massett on the Queen Charlotte Islands to fund the project by promising that it would be possible to sell carbon credits for the carbon dioxide taken up by phytoplankton.

The reality was much more complex, and it underscores the combustible politics and uncertain science of geoengineering.

Contacted by Nature, George lashed out at the media and "radical environmentalists" for manufacturing a "racist" story about a maverick geoengineer taking advantage of naive natives. "This was their work and their project," he says. "It is not the result of them being too stupid to know better."

It is now clear that Old Massett, a fishing village of fewer than 1,000 people, embraced the project in hopes of restoring dwindling salmon runs by boosting phytoplankton and, in turn, the entire marine food web. Villagers voted in February 2011 to lend Can\$2.5 million (US\$2.5 million) to the Haida Salmon Restoration Corporation (HSRC) to fertilize the ocean, says John Disney, head of the Old Massett-based corporation and economicdevelopment officer for the village. George, who previously headed Planktos, a firm based in San Francisco, California, that had sought to commercialize ocean fertilization using iron, signed on as chief scientist after the HSRC approached him, says Disney. The company planned to repay the village for its loan by selling carbon credits to companies seeking to offset their greenhouse-gas emissions, he adds.

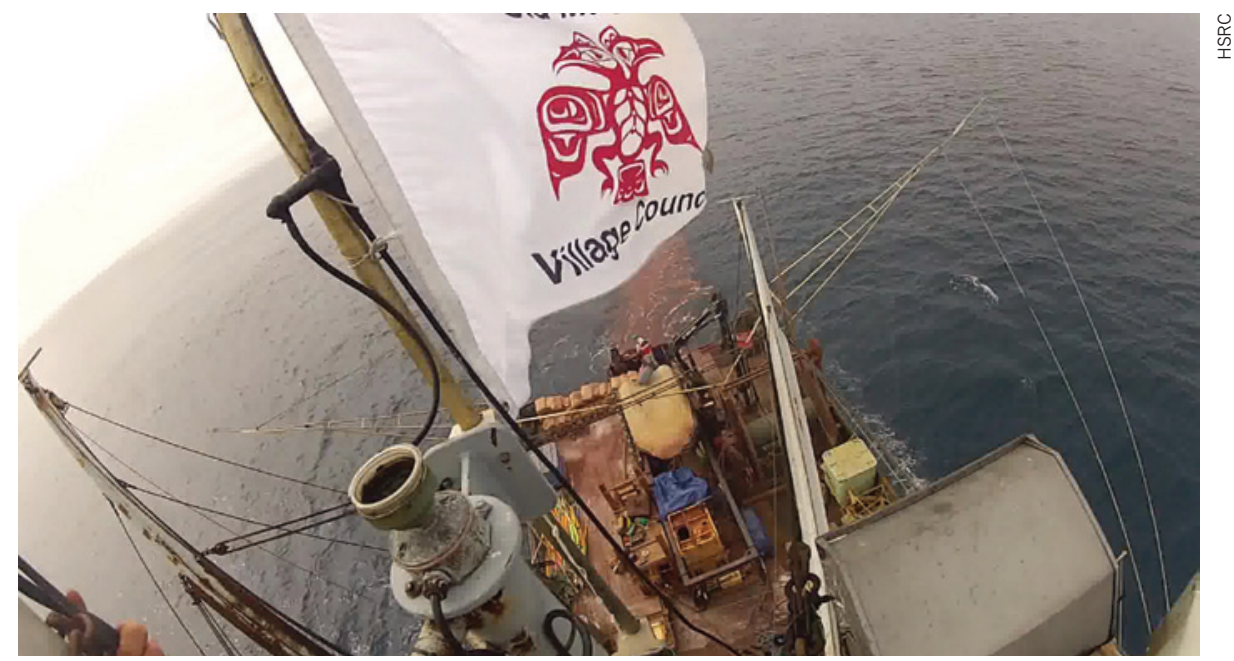

Workers on a Haida Salmon Restoration Corporation boat release iron sulphate into the Pacific Ocean.

"We created life where there wasn't life," says Disney, adding that the fertilization fed a phytoplankton bloom of some 10,000 square kilometres, which attracted fish, birds and whales (see 'Sowing controversy'). "The only difference between what we've done and what everybody else has done is that we've taken it up a notch."

In fact, the Old Massett scheme dumped five times more iron than previous fertilization experiments. And no scientists outside the project have seen data that might show whether it worked as advertised. "I'm not going to condemn it offhand, but this is just not the way to do this experiment," says Victor Smetacek, a marine biologist with the

\section{SOWING CONTROVERSY}

A company backed by a Canadian indigenous group has attempted to fertilize a region of the Pacific Ocean important for salmon stocks.

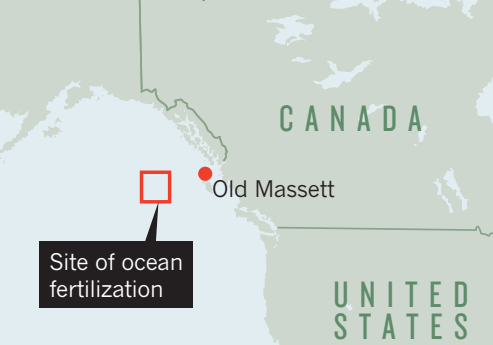

Alfred Wegener Institute for Polar and Marine Research in Bremerhaven, Germany. "It's quite sophisticated science, and it would have been good if scientists had carried it out."

The project was also on uncertain legal grounds. Ocean fertilization is restricted by a voluntary international moratorium on geoengineering, as well as a treaty on ocean pollution. Both agreements include exemptions for research, and the treaty calls on national environment agencies to regulate experiments. Officials from Environment Canada say that the agency warned project leaders in May that ocean fertilization would require a permit.

"Environment Canada did not approve this non-scientific event," environment minister Peter Kent told Parliament on 18 October. "Enforcement officers are now investigating." The Canadian National Research Council gave nearly Can\$70,000 in funding to the HSRC, and the US National Oceanic and Atmospheric Administration provided 20 buoys to help to monitor water conditions. But officials at those agencies say they were never informed of the ocean-fertilization project, and they thought that the work involved salmon ecology.

Jason Blackstock, a geoengineering expert at the University of Oxford, UK, says that the situation highlights the grey area between geoengineering to alter global climate, and local actions with other goals such as boosting salmon stocks or seeding clouds for weather modification. "This has the potential to become a ubiquitous 
problem," says Blackstock.

The ETC Group, an advocacy organization based in Ottawa that has led a global drive against geoengineering, has suggested that George misrepresented the project's potential to generate carbon credits. Documents from the Old Massett website imply that in raising funds, project leaders stressed the potential for easy carbon credits. One document, tied to a 2011 loan application, showed that bank managers were wary of the HSRC's claims that the market for such carbon offsets was proven and that "retail outlets and banks in Germany are begging for the product".

In fact, carbon credits from iron-fertilization projects cannot be offered on formal markets such as the European emissions trading system, although willing buyers might be found outside those markets. And whether iron fertilization actually sequesters carbon is uncertain. A study ${ }^{1}$ by Smetacek published in July — based on analysis of an experiment in 2004 - found that at least half of the carbon taken up by the iron-fertilized plankton was buried after they sank to the bottom of the sea. But other studies ${ }^{2}$ have found that carbon in the blooms remains in the active biological cycle and is not sequestered at all.

George says that the bankers were ultimately satisfied, and that carbon credits are no more than a possible source of future funding, if the science supports them. But in an initial interview, Disney repeatedly said that the company needs to sell the carbon credits quickly to repay its loan from the community. "Being the guy who sold this to the community, I bloody well better come up with the money," he said. Disney later backed off his emphasis on carbon credits and stressed that he stands by George.

It is unclear whether the project will restore the salmon. A bumper run of sockeye salmon (Oncorhynchus nerka) in 2010 came two years after a volcanic eruption in Alaska sent a layer of iron-rich ash over the ocean, fertilizing a plankton bloom ${ }^{3}$. But many scientists remain sceptical.

Whether the Haida experiment worked won't be known for two years, when the youngest of the salmon feeding in the ocean today return home to spawn. John Nightingale, president of the Vancouver Aquarium in Canada, says that will be a chance to glean some science from the project. The work may have lacked scientific rigour, he says, but the HSRC has now agreed to make all of its data available to scientists. It has "done something unique", Nightingale says. "I want the maximum information, the maximum analysis, the maximum debate."

1. Smetacek, V. et al. Nature 487, 313-319 (2012).

2. Boyd, P. W. et al. Nature 407, 695-702 (2000).

3. Jones, N. Nature http://dx.doi.org/10.1038/ news.2010.572 (2010).

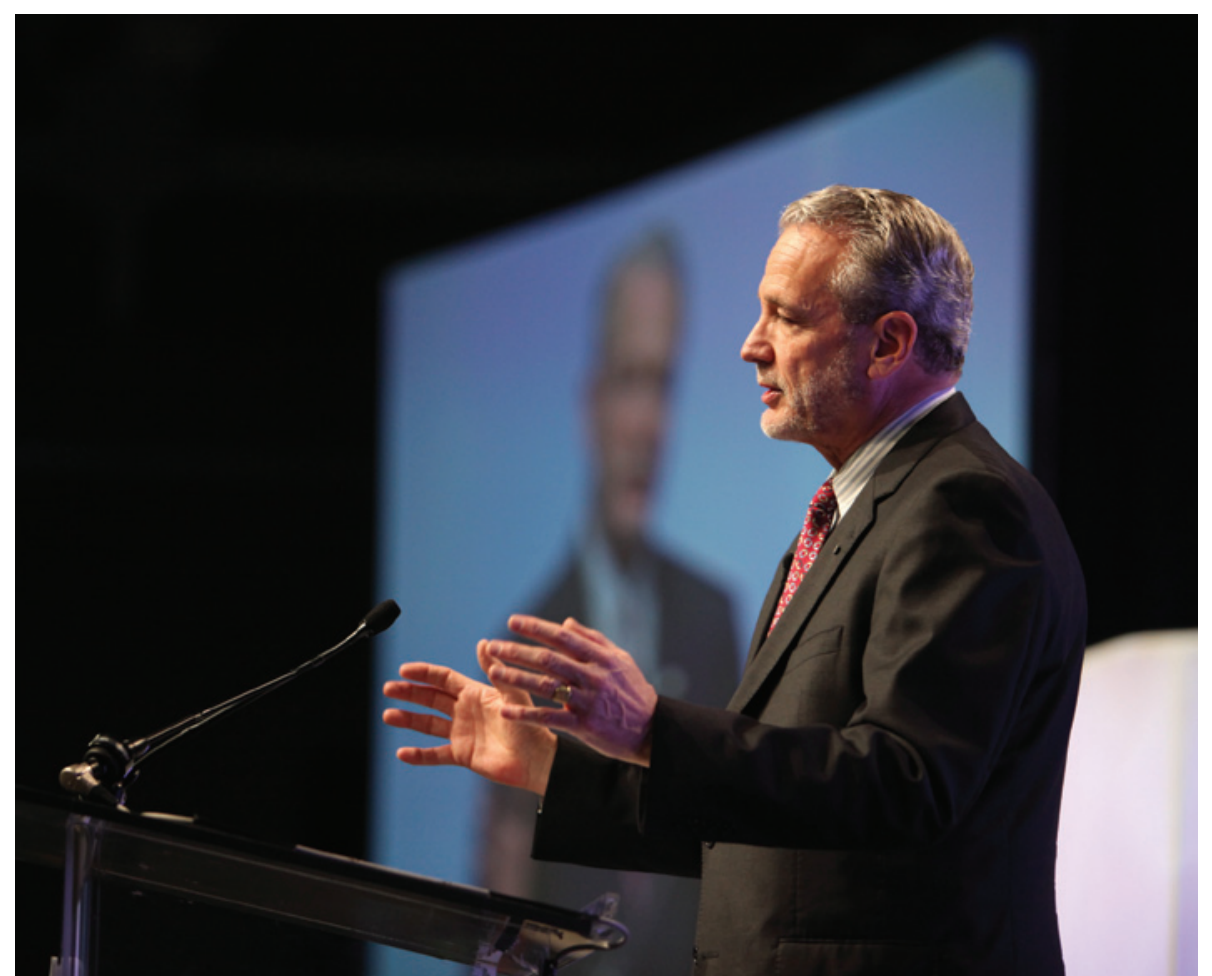

William Gimson of the Cancer Prevention and Research Institute of Texas is on the hunt for a chief scientist.

PEER REVIEW

\section{Texas cancer fund seeks fresh start}

\section{Critics question whether institute has resolved conflicts between commercial and scientific goals.}

\section{BY MONYA BAKER}

I t must be hard filling a position when the last person in the job was a Nobel laureate who quit in protest over a disregard for peer review, and whose departure triggered an avalanche of other resignations. Nevertheless, the Cancer Prevention and Research Institute of Texas (CPRIT) is confident that it will announce a chief scientific officer to replace Alfred Gilman, who departed on 12 October, by the end of the year. But institute watchers suspect that even an ideal candidate might not be able to dispel the science community's unease about the CPRIT's attempt to simultaneously support basic research and nurture companies.

"I can't think of a better example than this one of how a potential conflict of interest can undermine an institution," says Paul Root Wolpe, a bioethicist at Emory University in Atlanta, Georgia.

The Austin-based CPRIT was created in 2007 when Texas voters agreed to a US $\$ 3$-billion

initiative that would spend $\$ 300$ million a year to advance basic research, reduce cancer rates and nurture Texas companies. Since then, the state agency has awarded 427 grants totalling more than $\$ 750$ million, with $\$ 574$ million designated for scientific research and the rest for commercialization and prevention. Its funding of innovative research has won accolades.

Controversy erupted in May after Gilman, who won the 1994 medicine Nobel, tendered his resignation in a strongly worded letter criticizing a \$20-million commercial 'incubator' grant that had been awarded without scientific review. Much of the grant was slated for a group led by Lynda Chin at the University of Texas MD Anderson Cancer Center in Houston, where Chin's husband, Ronald

$\rightarrow$ NATURE.COM Read an interview with a former CPRIT scientific reviewer: go.nature.com/rxa4yl
DePinho, is president. CPRIT internal correspondence that was subsequently made public through freedom-ofinformation rules 